\title{
Food security assessment of NGO supported and own managed pond fish farmers of two districts in Bangladesh
}

\author{
K. Akhi ${ }^{1}$, M. T. Uddin ${ }^{2}$ and M. M. Islam ${ }^{3}$ \\ ${ }^{1}$ Department of Agricultural Economics and Policy, Sylhet Agricultural University, Sylhet-3100, ${ }^{283}$ Department of \\ Agricultural Economics, Bangladesh Agricultural University, Mymensingh-2202, Bangladesh \\ *Email: tajbau@yahoo.com
}

\begin{abstract}
The study was conducted to assess the food security status of pond fish farming under NGO supported and own managed and to evaluate the influential factors of NGOs' intervention on pond fish farmers' food security in two districts of Bangladesh. Random sampling technique was used to select farmers from two groups of pond fish farming: one is NGO supported and another is own managed farmers. A total of 120 farmers (60 for NGO supported and 60 for own managed) were selected for data collection. To identify the factors influencing the food security status of fish farming households, a food security index $(Z)$ was constructed and food security status of each household was determined based on the food security line using the recommended daily calorie intake approach. Logit model was used to estimate the food security status of households as a function of a set of independent determinants. Based on the recommended daily calorie intake of $2122 \mathrm{kcal}$, it is observed that 95 percent of the households were food secure and 5 percent households were food insecure in case of NGO supported fish farmers. On the other hand, 30 percent of the households were food secure and 70 percent households were food insecure in case of own managed fish farmers. The result of logit model shows that six out of eight variables included in the model were significant in explaining the variation in food security status. These variables were: age of the household head, education level of the household head, farm size, intervention on fish farming, income from fish and non-farm income. The study, therefore, recommended improved access to technical supports of pond fish farming households is necessary to ensure food security status at the national level.
\end{abstract}

Keywords: Food security, NGO supported, Own managed, Pond fish farmers

\section{Introduction}

Bangladesh is predominantly an agricultural country where agriculture sector plays a pivotal role in accelerating the economic growth. It is often argued that the future development of the country depends particularly on the agriculture sector. During the fiscal year 2012-13, the broad agriculture sector contributed $16.3 \%$ to the total GDP (BER, 2014). Nearly three fifth of the agricultural GDP comes from the crop sub-sector; the other contributors in order of magnitude are fishery, livestock and forestry. The growth rate of agricultural GDP was $4.5 \%$ and the rates for fisheries, forestry, livestock and crop subsectors were $6.2 \%, 5.1 \%, 2.8 \%$ and $1.9 \%$, respectively (BER, 2014).

Bangladesh is considered as one of the most suitable countries in the world for small-scale fresh water rural aquaculture for its favorable resources and agro climatic conditions, but it has a massive population. Provision for food for all, is therefore, a real challenge and Bangladesh may have to depend in some extent on imported food to ensure food security. Thus, food security and poverty reduction are mainstays of government development efforts. To achieve these goals, the government of Bangladesh prioritizes diversified production, employment and income generation on farms in its Poverty Reduction Strategy Paper (PRSP). In order to ensure food security and to reduce poverty, the committed target is to achieve self-sufficiency in food through increased crops production, sustainable growth of agriculture sector and employment opportunity as envisaged in National Strategy for Accelerated Poverty Reduction (NSAPR), National Agricultural Policy (NAP) and Millennium Development Goals (MDGs).

Most of the ponds are utilized mainly for domestic purposes such as bathing for human and domestic animals, washing clothes and utensils, irrigating crop fields and so on. Ponds cover only $3.5 \%$ of the total inland waters of Bangladesh whereas they contribute about $31 \%$ of the total inland fish production and thereby play a vital role in fresh water fish production. Fish catches and production are not keeping pace with growing need of population. Over the decade, annual per capita fish consumption has declined sharply in Bangladesh. In others words, there is a great shortage of fish production in this country and this situation is gradually aggravating due to rapid growth of population. Increased aquaculture production can help to meet protein availability. 
Food security encompasses three elements: availability, accessibility and utilization (USAID, 1996). Food availability refers to the physical presence of food at various levels from household to national level, be that from own production or through markets (FANTA, 2006). Food access refers to the ability to obtain an appropriate and nutritious diet and is, in particular, linked to resources at the household level. Food utilization refers to the proper use of food, which includes the existence of proper food processing and storage practices, adequate knowledge and application of nutrition and child care, and adequate health and sanitation services (FANTA, 2006). In our country, the natural annual fish production cannot meet the increasing demand of the human population which results in pressure on aquaculture to enhance the production. Continuous efforts are being made to increase fish production from locally available sources. Bangladesh has a great potentiality to increase inland fish production. To fulfill the deficit of animal protein to achieve households' food security, there is crying need to cultivate quick growing fish under scientific methods and management. Pond fish culture can be expected to play an important role in supplying required fish to the people. Pond fish culture can also be a major income generating activity in rural development programs. Supplemented with agricultural crop production and animal husbandry, pond fish culture can generate income and employment in the rural areas and improve the quality of life of the rural poor. Thus, if the existing ponds are brought under semi intensive fish culture, the present rate of pond culture production can easily be increased which will ultimately help households to become food secured.

Bangladesh enjoys enormous aquatic resources and capture fisheries which have been extensively utilized for centuries. Fisheries as one of the most productive and dynamic sub-sector plays a significant role in employment, nutrition, and foreign exchange earnings in the economy of Bangladesh. Bangladesh has been among the top five fish cultivation countries for many years. According to the United Nations Food and Agriculture Organization (2014), Bangladesh presently stands fourth in producing sweet water fish. In 2012-13, fisheries alone managed to perform with a GDP growth rate (6.2\%) at a time when the sub-sector has been marked by a radical structural transformation with the spread of organized and commercially-oriented aquaculture (PC, 2014). Experts say that the fish farmers reached this level of success after crossing many hurdles. In the 2013-14 fiscal year, fish farmers received only $10 \%$ of the 140 billion taka allocated as agricultural loans. In 2013-14, Bangladesh government disbursed US\$179.5 million as agricultural loans to fish farmers.

The studies relevant to some context in terms of research methodology and findings have been conducted in the recent past are: Akter et al. (2014) investigated household's food security status of selfassessed through a module and found that $45 \%$ of the households interviewed experienced food shortages at least once during the three preceding years of the survey; Begum et al. (2013) investigated the present status and trend of food security in Bangladesh which indicates that Bangladesh is not currently food secure in the sense of share of the total energy coming from protein and fat; Mannaf (2012) conducted a research on maize production and its impact on food security in selected areas of Bogra district and pointed out that four variables (i.e., age of household head, household size, agricultural income and food expenditure) have significant influence on household's food security condition; and Akhter (2009) assessed the factors affecting the pond fish farming and observed that most of the included variables had significant impact on pond fish production. Most of the studies dealt with cost, return, profitability and productivity of pond fish farming at the farmer's own managed and determine the factors affecting food insecurity, self sufficiency in food production in Bangladesh. But there is no study that will help to determine more profitable practices of pond fish farming and thereby improve food security status of farm households.

To minimize this research gap, this study is designed to generate valuable information on socioeconomic aspects of farmers involved with NGO assisted pond fish production in comparison to own managed pond fish culture. However, it is essential to perform a socioeconomic study and make an investigation on food security in respect of assessment of NGO sponsored pond fish culture with farmers' own management. Till date, very little attempts have been made in this regard. This study determines the factors both quantitative and qualitative which influence food security status of the fish farmers. So, this study would be informative in this field. The present study is expected to demonstrate how much better off the farmers have become through NGOs' credit and technical support. Therefore, the proposed study attempts to 
focus on an appropriate and timely topic of research. The goal of this study is to compare the food security status of NGO supported and own managed pond fish farmers and to evaluate the average impact of the intervention of NGOs' on fish farming. The specific objectives addressed in the study are: a) to estimate the extent of food security status of pond fish farmers; and b) to determine the factors that influence the fish farm household's food security status.

\section{Materials and Methods}

A study usually requires selection of an area for collecting data in accordance with the objectives set for the study. Seven villages namely, Chornikhola, Chorhosenpur, Chorshiari, Harua, Monohorpur, Kumrashashon, Ashrobpur from Ishwarganj upazila under Mymensingh district and eight villages namely, Basudebbari, Maijbari, Kodimfosol, Chakondomul bari, Tholbari, Vottobari, Lokhipur, Jotabari from Madhupur upazila under Tangail district were selected for this study. In these areas, government and several non-government organizations (NGOs) such as BRAC, PROSHIKA, ASA, SSS, etc. have undertaken a laudable program for pond fish culture through extending credit and technological support. A sample of representative farms is chosen in such a way that the information meets the purpose of the study. Random sampling technique was used to select farmers from two groups of pond fish farming; one is NGO supported farmers and another is own managed. A total of 120 farmers (60 for NGO supported and 60 for own managed) were selected for primary data collection.

\section{Analytical techniques}

To identify the factors influencing the food security status of fish farming households, a food security index $(Z)$ was constructed and food security status of each household was determined based on the food security line using the recommended daily calorie intake approach and then a logit model was used to estimate the food security status of households as a function of a set of independent determinants. A household which daily per capita calorie intake up to $2122 \mathrm{kcal}$ was regarded as food secure and those below $2122 \mathrm{kcal}$ were regarded as food insecure households. The mathematical representations are as follows:

$$
\begin{aligned}
& Z_{i}=Y_{i} / R \\
& W h e r e, \\
& Z_{i}=\text { Food security status of } i^{\text {th }} \text { households which take values of } 1 \text { for food secured } \\
& \quad \text { households or } 0 \text { for food insecured households; } \\
& Y_{i}=\text { Daily per capita calorie intake of } i^{\text {th }} \text { household; and } \\
& R=\text { Recommended per capita daily calorie intake. }
\end{aligned}
$$

Additionally, the food insecurity gap and the surplus index were calculated for the sample households based on food security line.

\section{Surplus or Shortfall Index}

The tool was used to measure the extent to which a household is food secure or insecure. The index is given as:

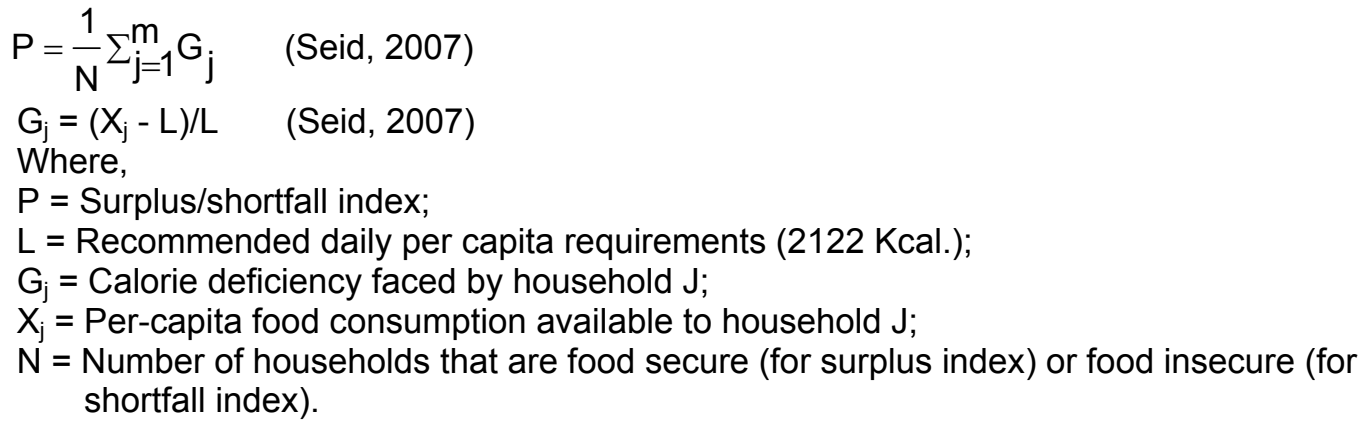


Based on the household food security index (Z), the Logit model was estimated to identify the determinants of food security. The implicit form of the model was as follows:

$$
\begin{aligned}
& Y_{i}=\beta Q_{i}+U_{i} \\
& \text { Where, } \\
& Y_{i}=1 \text { households are food secured and } Y_{i}=0 \text { otherwise; } \\
& Q_{i}=\text { Vector of explanatory variables; } \\
& U_{i}=\text { Error term; and } \\
& \beta=\text { Vector of parameter estimates. }
\end{aligned}
$$

The independent variables are captured as:

$Q_{1}=$ Age of household head (Years);

$\mathrm{Q}_{2}=$ Educational level of household head (Years of schooling);

$\mathrm{Q}_{3}=$ Farm size (ha);

$\mathrm{Q}_{4}=$ Pond size (ha);

$\mathrm{Q}_{5}=$ Intervention on fish farming (Dummy);

$\mathrm{Q}_{6}=$ Income from fish farming (Tk. /month);

$\mathrm{Q}_{7}=$ Income from rice production (Tk. /month); and

$\mathrm{Q}_{8}=$ Non-farm income (Tk./month).

\section{Results and Discussion}

\section{Incentives provided to pond fish farming by NGOs}

Supported pond fish farmers got different types of facilities from NGO organizations (Table 1). These provide agricultural credit to farmers, micro-credits to women and landless farmers at a reasonable interest rate. Besides these, NGOs are also providing technical training on poultry and livestock rearing. They also provide educational facilities for village poor children. There are other NGOs named Caritas, Gono shahajjo Sangstha, World Vision, Adarsha Samaj Sheba Samiti, NGO Forum, etc working in the study areas. SSS (Society for Social Service) is the main NGO who works in the study areas in fisheries sub-sector. Fish farmers are benefitted through its activities. SSS provides preliminary help to the fish farmers through credit, training, etc. It also offers post harvest services for product selling and marketing. These interventions can be measured as cash incentives and kind incentives. Cash incentives included credit facilities and fingerlings received by the fish farmers and kind incentives included training, product selling, monitoring and technical supports. On an average, fish farmer received cash incentives of Tk. 9612 in Ishwarganj and Tk. 9293 in Modhupur upazila. Kind incentives are equivalent to monetary value of Tk. 300 in Ishwarganj and Tk. 432.5 in Modhupur upazila.

Table 1. Distribution of sampled farmers based on nature of NGO intervention

\begin{tabular}{l|c|c|c|c}
\hline \multirow{2}{*}{ Types of intervention } & \multicolumn{2}{|c|}{ Ishwarganj } & \multicolumn{2}{c}{ Modhupur } \\
\cline { 2 - 5 } & No. & $\%$ & No. & $\%$ \\
\hline Credit & 13 & 21.7 & 11 & 18.3 \\
Fingerlings & 11 & 18.3 & 16 & 26.7 \\
Training & 29 & 48.3 & 21 & 35.0 \\
Product selling & 37 & 61.7 & 24 & 40.0 \\
Monitoring & 41 & 68.3 & 39 & 65.0 \\
Technical supports & 28 & 46.7 & 18 & 30.0 \\
Training + Monitoring & 22 & 36.7 & 16 & 26.7 \\
Monitoring + Product selling & 35 & 58.3 & 31 & 51.7 \\
Credit + Training + Monitoring & 2 & 3.3 & 3 & 5.0 \\
\hline
\end{tabular}

Source: Field survey, 2013. 
These types of cash and kind incentives lead fish farmers to become more beneficial than the own managed fish farmers.

Table 2. Incentives provided to pond fish farming by different NGOs (Tk. I farm)

\begin{tabular}{|c|c|c|}
\hline Types of intervention & Ishwarganj & Modhupur \\
\hline \multicolumn{3}{|c|}{ Cash incentives } \\
\hline Credit & 18200 & 17340 \\
\hline Fingerlings & 1024 & 1246 \\
\hline Average & 9612 & 9293 \\
\hline \multicolumn{3}{|c|}{ Kind incentives } \\
\hline Training & 300 & 350 \\
\hline Product selling & 410 & 500 \\
\hline Monitoring & 800 & 770 \\
\hline Technical services & 90 & 110 \\
\hline Total & 1200 & 1730 \\
\hline Average & 300 & 432.5 \\
\hline
\end{tabular}

Source: Field survey, 2013.

\section{Food security status of pond fish farmers}

To measure household food security, a food security index was constructed. Daily per capita calorie consumption was estimated by dividing the estimated daily calorie supply to the household by the household size (Babatunde et al., 2007). Household calorie availability was estimated using food nutrient composition. Table 3 shows that daily per capita calorie intake from different food items was highest in NGO supported household and it was $2233.9 \mathrm{kcal}$, whereas, in case of own managed fish farmers, the value was $1955.3 \mathrm{kcal}$.

Based on this above mentioned information, food security index $(Z)$ was calculated for own managed and NGO supported fish farmers. Additionally, the food insecurity gap or the surplus index $(P)$ was calculated for the sample households based on the food poverty line. The food insecurity gap measures the extent to which poor households are found insecure and the surplus index measures the extent by which food secure households exceeded the food poverty line. Table 4 presents the food security indices for two groups of fish farmers.

Table 3. Calorie intake from different items by family members of the household (kcal)

\begin{tabular}{l|c|c}
\hline Food items & NGO supported & Own managed \\
\hline Rice & 1861.3 & 1622.1 \\
Wheat & 34.6 & 32.1 \\
Pulses & 24.5 & 19.3 \\
Vegetables & 87.5 & 75.3 \\
Fish & 26.8 & 22.6 \\
Meat & 4.5 & 2.1 \\
Egg & 7.5 & 5.6 \\
Milk and milk products & 4.8 & 2.5 \\
Fruits & 5.1 & 4.8 \\
Sugar or gur & 4.6 & 4.5 \\
Spices & 12.6 & 10.2 \\
Edible oil & 160.1 & 154.2 \\
\hline Average & 2233.9 & 1955.3 \\
\hline
\end{tabular}

Source: Authors' estimation based on field survey, 2013. 
Table 4 also represents that 95 percent of the households were food secure and 5 percent households were food insecure in case of NGO supported fish farmers, while for own managed fish farmers, food secure households were 30 and 70 percent, respectively.

Table 4. Food security indices for two groups of pond fish farmers

\begin{tabular}{|c|c|c|c|c|}
\hline $\begin{array}{l}\text { Groups of } \\
\text { fish farmers }\end{array}$ & Food security indices & $\begin{array}{l}\text { Food secure } \\
\text { households }\end{array}$ & $\begin{array}{c}\text { Food insecure } \\
\text { households }\end{array}$ & All \\
\hline NGO & Food security index $(Z)$ & 1.06 & 0.89 & 1.05 \\
\hline \multirow{3}{*}{ supported } & Percentage of households (\%) & 95.0 & 5.0 & 100.0 \\
\hline & Per capita daily calorie availability (Kcal.) & 2252.6 & 1878.8 & 2233.9 \\
\hline & Food insecurity gap/surplus index $(P)$ & 0.06 & -0.11 & - \\
\hline Own & Food security index $(Z)$ & 1.08 & 0.85 & 0.92 \\
\hline \multirow[t]{3}{*}{ managed } & Percentage of households (\%) & 30.0 & 70.0 & 100.0 \\
\hline & Per capita daily calorie availability (Kcal.) & 2291.0 & 1811.4 & 1955.3 \\
\hline & Food insecurity gap/surplus index $(P)$ & 0.08 & -0.15 & - \\
\hline
\end{tabular}

Source: Authors' estimation based on field survey, 2013.

The food security index for NGO supported fish farmers was 1.05, whereas 1.06 for food secure household and 0.89 for food insecure households. For own managed fish farmers, the average food security index was 0.92 consisted of 1.08 and 0.85 for food secure and insecure households, respectively (Table 4). The surplus index shows that the food secure households exceeded the calorie requirements by 6 percent but food insecure households fell short of the required calorie intake by 11 percent in case of NGO supported fish farmers. Based on the recommended daily calorie intake of $2122 \mathrm{kcal}$, it was observed that in case of food security gap or surplus index for own managed fish farmers, the food secure households exceeded the food poverty line by 8 percent, while food insecure households fell short of the required calorie intake by 15 percent.

So the study found that households under NGO supported had greater food security status than the own managed pond fish farm households. So, NGO support and services has positive influence to attain households food security as well as to reduce the extent of food insecurity.

\section{Determinants of Pond Fish Farm Households' Food Security}

A logit model has been eliciting the factors influencing the food security status of the fish farmers. Eight explanatory variables were identified as major determinants of food security for the present study. These variables were: age of household head, education level of the household head, farm size of the farmers, pond size of the farmers, household size, income from fish farming, income from rice production and nonfarm income of the fish farmers. All the factors were priori expected to have a positive impact on food security status of the selected farm households.

\section{Hypotheses for the logit model}

The model used the various household resources as the factors influencing food security and their anticipated effects on rural household's food security which are presented below:

Among the potential factor(s) influencing food security, age of a household head $\left(Q_{1}\right)$ is expected to have influence on food security. The assumption here was the higher the age of the head, the farmers are more efficient to produce pond fish and also more experienced than the younger one. With the experienced fish farmers, production will increase and income will also increase. So, there is a positive effect on household's food security.

Level of education of the household heads $\left(Q_{2}\right)$ could also have an influence on food security. Educational attainment by the household head could lead to increase in awareness of the possible advantage of modernizing fish farming by means of technological inputs and enable diversification of household income. In the survey, it is better to classify them based on their status of being literate (1) and illiterate (0). 
Farm size $\left(Q_{3}\right)$ is the total farm land cultivated by the farm household measured in hectare. The larger the farm size, the higher the production level. Among the small-scale fish farmers, who have large farm size they can take enough food. The expected effect on food security is positive.

Pond size $\left(Q_{4}\right)$ is another factor to affect the food security. The larger the pond size, total amount of fish production will be increased which fulfills the daily requirement of fish and other protein requirement. The expected effect of this variable on food security is positive.

Intervention on fish farming $\left(Q_{5}\right)$ could also have an influence on household's food security. Different NGO interventions in fish farming could lead to modernize fish farming by means of technological inputs and enable to increase household income. In this study, fish farmers are classified into two groups NGO supported and own managed. Thus, the NGO supported fish farmers take a value of 1 while those who are own managed fish farmers take a value of 0 .

Income from fish farming $\left(Q_{6}\right)$, as other demographic variable was also tested for any association with household's food security. Income from fish farming refers to the sum of the earnings of the households in a year from their fish farming. Higher the income from fish farming, farmers have to invest more to the fish farming. The expected effect of this variable on food security is positive.

Income from rice production $\left(Q_{7}\right)$ is one of the important factors in food security. Large portion of farm income comes from the rice farming which is very important to food security. Higher the income from rice farming, food security status of the farmers is increased accordingly.

Table 5. Estimates of the logistic regression of determinants of food security status of sampled pond fish farm households

\begin{tabular}{l|c|c|c|c}
\hline Variables & $\begin{array}{c}\text { Coefficient } \\
(()\end{array}$ & $\begin{array}{c}\text { Standard } \\
\text { error }\end{array}$ & $\begin{array}{c}\text { Level of } \\
\text { significance }\end{array}$ & Odds ratio \\
\hline Constant & -4.021 & 1.421 & 0.005 & 0.018 \\
Age of household head $\left(\mathrm{Q}_{1}\right)$ & $0.265^{* * *}$ & 0.080 & 0.001 & 1.304 \\
Education level of household head $\left(\mathrm{Q}_{2}\right)$ & $0.007^{* *}$ & 0.003 & 0.039 & 1.007 \\
Farm size $\left(\mathrm{Q}_{3}\right)$ & $0.012^{*}$ & 0.007 & 0.089 & 0.988 \\
Pond size $\left(\mathrm{Q}_{4}\right)$ & $0.153^{*}$ & 0.193 & 0.429 & 1.165 \\
Intervention on fish farming $\left(\mathrm{Q}_{5}\right)$ & $0.002^{*}$ & 0.001 & 0.072 & 1.002 \\
Income from fish farming $\left(\mathrm{Q}_{6}\right)$ & $0.00013^{*}$ & 0.00013 & 0.066 & 1.000 \\
Income from rice production $\left(\mathrm{Q}_{7}\right)$ & 0.00011 & 0.00011 & 0.816 & 1.000 \\
Non-farm income $\left(\mathrm{Q}_{8}\right)$ & $0.265^{* * *}$ & 0.080 & 0.001 & 1.304 \\
\hline
\end{tabular}

Source: Authors' calculation based on field survey, 2013.

Note: ${ }^{*} ;{ }^{* *}$; and ${ }^{* * *}$ Significant at 10 percent, 5 percent and 1 percent level, respectively.

Employment in non-farm activities or non-farm income $\left(Q_{8}\right)$ has a paramount significance to diversify the sources of farm households' livelihood. It enables farmers to modernize their production by giving them an opportunity for applying the necessary inputs and thereby reducing the risk of productivity. From this perspective, it was attempted to see whether any significant difference exists between households who worked in non-farm activities and those farmers who did not.

\section{Determinants of household's food security status of pond fish farmers}

The result of logit regression is presented in Table 5. The result shows that the model was accurate in explaining the determinants of household's food security. Six out of eight variables included in the model were significant in explaining the variation in food security in the study areas. These variables are: age of the household head, education level of the household head, farm size, intervention on fish farming, income from fish farming and non-farm income. The interpretation of significant variables are as follows: 


\section{Age of household head}

The result shows that the age of household head has a positive coefficient and it was 0.265 , which was significant at $1 \%$ level. It indicated that higher the age of the household head, the farm families are more food secured. One unit increase in the age of the household head will increase the probability of securing food by 1.304 units, keeping all other factors remaining constant. In other words, an increase in age of household by 1 percent will increase the odds of food security by 30.4 percent. The result is in line with the findings of Tefera et al., (2014).

\section{Education level of household head}

The level of education of the household heads has a positive coefficient which was significant at $5 \%$ level. That means, one unit increase in the level of education will increase the probability of food security by 1.007 units, holding all other factors constant. In other words, an increase in level of education by 1 percent will increase the odds of securing food by 0.7 percent. The finding was also supported by the research result of Tefera et al., (2014).

\section{Farm size}

The result shows that the farm size of the farmers has a positive coefficient and it was 0.012 , which was significant at $10 \%$ level. It indicated that the higher the farm size, the greater the probability of securing food. One unit increase in the farm size will increase the probability of fish farming by 0.988 unit.

\section{Intervention on fish farming}

Intervention on fish farming has a low but positive coefficient that was significant at $10 \%$ level. One unit increase in NGO intervention increases the probability of household to be food secured by 1.002 units. This result is expected because increase in the NGO support means technical supports will increase the probability of households being food secured which might lead to increase the productivity of fish farming as well.

\section{Income from fish farming}

This result implies that households' annual average income from fish farming has a positive coefficient which was 0.00013 and significant at $10 \%$ level. This indicates that the higher the household fish income, the higher is the probability that the household would be food secured. One unit increase in the level of income from fish farming will increase the probability of household to be food secured by 1.000 unit.

\section{Non-farm income}

Households' average non-farm income was positive and significant at $1 \%$ level. This indicates that the higher the household non-farm income, the higher is the probability that the household would be food secured. One unit increase in the level of non-farm income will increase the probability of household to be food secured by 1.304 units.

Based on the logit model, the following conclusions can be drawn as findings:

- A large percentages of households are food secured under NGO supported than own managed fish farm;

- The probability of household food security increases with the increase in age of household heads;

- The probability of household food security increases with the increase in education level of household head;

- The probability of household food security increases with the increase in farm size;

- Household food security positively related with NGO intervention;

- Food security analysis showed that one unit increase in fish farm income will increase the probability of the household being food secure; and

- The probability of household food security increases with the increase in non-farm income. 


\section{Conclusion and Recommendation}

Ensuring food security for the vast population of Bangladesh is directly associated with the agricultural development in the country. The government of Bangladesh has, therefore, been giving priorities to agricultural development in general with a view to ensuring food and nutritional security, poverty reduction and increased generation of employment through pond fish production as particular. In order to ensure food security through development of agriculture in Bangladesh, the invention, adoption and dissemination of new technology and agricultural credit disbursement must be ensured with a view to increasing production of diversified agriculture. In the light of the findings from the study, it is recommended that efforts to improve access to credit by farmers and the promotion of non-farm activities as alternative livelihood options should be pursued by government structures to improve the household food security situation in Bangladesh. Policies that will make micro-credit from government and nongovernmental agencies accessible to fish farmers will go a long way in addressing their resource acquisition constraints and eventually improving household food security in the country. There is a great impact of NGO on fish farmer's food security status. Therefore, it can be concluded that there is great scope to improve the livelihood condition of fish farmers in terms of better food security situation through the intervention of NGOs.

\section{References}

Akhter, M. 2009. An Economic Analysis of Pond Fish Culture in Some Selected Areas of Mymensingh District. An Unpublished M.S. Thesis, Department of Agricultural Economics, Bangladesh Agricultural University, Mymensingh.

Akter, S. and Basher, S.A. 2014. The impacts of food price and income shocks on household food security and economic wellbeing: Evidence from rural Bangladesh. Global Environmental Change, Vol. 25, pp. 150-162.

Babatunde, R.O., Omotesho, O.A. and Sholotan, O.S. 2007. Factors influencing food security status of rural farming households in North Central Nigeria, Agri. J., 2(3), 351-357.

Begum, M.E.A., Hossain, M.I., and D'Haese, L. 2013. Food security in Bangladesh: Present status and trend. J. Prog. Agri. Vol. 24 (1\&2), pp. 263-271.

BER, 2014. Bangladesh Economic Review, Economic Advisers Wing, Finance Division, Ministry of Finance, Government of the People's Republic of Bangladesh.

FANTA, 2006. Food and nutrition technical assistance, Food Security, http://www.fantaproject.org/focus/food security. shtml (Last consulted: July 11, 2007).

FAO, 2014. World Food Summit. Food and Agriculture Organization, Rome, Italy.

Hossain, M. and Deb, U. 2011. Crop agriculture and agrarian reforms in Bangladesh: present status and future options. In, Mujeri, M.K. and Alam, S. (ed). Sixth Five Year Plan of Bangladesh 2011-2015, Background Papers. Vol. 2, Economic Sectors, Dhaka.

Mannaf, M. 2012. An economic study on maize production and its impact on food security in selected areas of Bogra district. M.S. Thesis, Department of Agricultural Economics, Bangladesh Agricultural University, Mymensingh-2202.

PC, 2009. Background Studies for the Sixth Five Year Plan (2011-2015): Planning Commission, Ministry of Planning, Government of the People's Republic of Bangladesh, Dhaka, Bangladesh.

Seid, F.F. 2007. Food insecurity and its determinants in Amhara region. M.S. thesis, Department of Economics, Addis Ababa University, Ethiopia.

Tefera,T. and Tefera, F. 2014. Determinants of household food security and coping strategies for food shortfall in Mareko district, Guraghe zone southern Ethiopia. J. Food Secu., 2(3), 92-99.

USAID, 1996. Annual Food Assistance Report (PN-ABZ-119). United State Agency for International Development. 